\title{
PEMIKIRAN POLITIK LOKAL: SEJARAH PEMBENTUKAN PROVINSI SULAWESI TENGAH
}

\author{
Haliadi \\ Leo Agustino \\ e-mail: adi.sadi@gmail.com
}

\begin{abstract}
ABSTRAK
Fenomena kemapanan dalam sejarah sebagai wujud integrasi tidak terjadi begitu saja, namun biasanya dimulai dari sebuah usaha yang disebut persepadudigabung (integrated) untuk menuju penubuhan yang dimaksudkan. Integrasi sosial tidak pernah dapat dicapai dengan sempurnah, namun secara fundamental sistem sosial selalu cenderung bergerak ke arah equilibrium yang bersifat dinamis: menanggapi perubahan-perubahan yang datang dari luar dengan kecenderungan memelihara agar perubahan-perubahan yang terjadi di dalam sistem sebagai akibatnya hanya akan tercapai derajat yang minimal. Biasanya integrasi terealisasi dalam sejarah kedalam dua perkara yang berbeda, yaitu integrasi secara positif dan integrasi secara negatif. Artikel ini akan mendedahkan integrasi secara positif yang terlihat dalam bentuk pemikiran politik - delapan Konsepsi Pembentukan Provinsi Sulawesi Tengah - elite tempatan di Sulawesi Tengah, Indonesia dalam proses terbentuknya Provinsi Sulawesi Tengah setelah mekar dari Provinsi Sulawesi Utara Tengah pada tahun 1964. Demikian juga integrasi secara negatif biasanya tidak diharapkan oleh masyarakat kerana kecenderungannya ke arah konflik dan terbukti pada perjuangan dalam Gerakan Pemuda Sulawesi Tengah (GPST) dalam mengusir Permesta sejak tahun 1957 dari Sulawesi Tengah. Hujah utama kertas kerja ini adalah pemekaran bukan hanya terkonsepsi dari pusat kekuasaan tetapi juga menurut pemikiran-pemikran politik tempatan daripada peringkat daerah (history of below).
\end{abstract}

Kata Kunci: Provinsi, Pemikiran, Politik Lokal.

\section{ABSTRACT}

The establishment phenomenon in history as integracy creation did not just happened, but it is usually start from an efforts that called integrated development toward to embodiment which is intended. Social integration never be reached perfectly. But fundamentally, social system always be moving to dynamic 
equilibrium; respond the changes which come in from outside with propensity to keeping in order the changes which is happened in the system and its consequence only reached minimal degree. Usually, integration realized in history to two problems that are integration positively and integration negatively. This paper will be placemented the integration positively that seen in political thought - eight concept for formation of Middle Sulawesi Province - placement elite in Middle Sulawesi, Indonesia in formation processes of Middle Sulawesi Province after separated from Middle-North Sulawesi Province in 1964. Thus, also integration negatively usually not being expected by community because it propensity to conflict and it has proved in struggling of Young Middle Sulawesi Movement (GPST) when they drived out Permesta during 1957 from Middle Sulawesi. The viewpoint on this paper is separation not only concepted from center of power but also based on political thoughs that is placed from history of below.

Keywords: Province, Thoughs, Local Politic.

\section{Pendahuluan}

Historiografi Indonesia belum tuntas membincangkan tema sejarah politik sehingga perlu mengkaji secara mendalam. Hal itu erat kaitannya dengan subtema "Otonomi dan Pemekaran Wilayah Administratif." Pada tingkal lokal, sejarah Indonesia belum banyak menyoroti tentang upaya dinamika pembentukan pemerintah tingkat provinsi dan kabupaten/kota sehingga segmentasi pengalaman lokal tidak banyak dihadirkan dalam wacana sejarah nasional Indonesia. Barbara Sillars Harvey (1989a; 1989b) dan Leirisa (1997) telah membahas Permesta sebagai gerakan politik lokal yang menginginkan otonomi sejak tahun 1957 di Pulau Sulawesi (baca: Sulawesi Selatan dan Sulawesi Utara). Namun, apakah permesta mendapatkan tantangan di tingkat lokal sebagai bentuk ketidaksetujuan anak daerah terhadap gerakan tersebut?

Pertanyaan tersebut di atas belum banyak dijawab dalam dua kajian tersebut, sehingga perlu kiranya merekonstruksi kembali sekaligus mengembangkan analisis "pemikiran pelaku sejarah" untuk menyoroti "pemikiran politik tokoh lokal di Sulawesi Tengah" pada tahun 1950-1963 sebagai bentuk reaksi lokal terhadap pembentukan Provinsi Sulawesi Tenggah dari Provinsi Sulawesi Utara Tengah.

Wilayah sorotan kajian ini adalah Provinsi Sulawesi Tengah yang sekarang ini terbahagi menjadi sebelas kabupaten dan kota, yaitu: Kota Palu, Kabupaten Donggala, Kabupaten Tolitoli, Kabupaten Buol, Kabupaten Parigi Moutong, Kabupaten Sigi, Kabupaten Poso, Kabupaten Morowali, Kabupaten Tojo Una-Una, 
Kabupaten Banggai, dan Kabupaten Banggai Kepulauan. Provinsi ini memiliki $^{130}$ luas daratan $61.841,29$ $\mathrm{km}^{2}$, dengan penduduk 2.633.420 jiwa, dan tingkat kepadatan penduduk 43 jiwa $/ \mathrm{km}^{2}$. Penduduk asli Sulawesi Tengah terdiri atas 15 kelompok etnis atau suku, yaitu: Etnis Kaili berdiam di kabupaten Donggala dan kota Palu, Etnis Kulawi berdiam di kabupaten Donggala, Etnis Lore berdiam di kabupaten Poso, Etnis Pamona berdiam di kabupaten Poso, Etnis Mori berdiam di kabupaten Morowali, Etnis Bungku berdiam di kabupaten Morowali, Etnis Saluan atau Loinang berdiam di kabupaten Banggai, Etnis Balantak berdiam di kabupaten Banggai, Etnis Mamasa berdiam di kabupaten Banggai, Etnis Taa berdiam di kabupaten Banggai, Etnis Bare'e berdiam di kabupaten Touna, Etnis Banggai berdiam di Banggai Kepulauan, Etnis Buol mendiami kabupaten Buol, Etnis Tolitoli berdiam di kabupaten Tolitoli, Etnis Tomini mendiami kabupaten Parigi Moutong, Etnis Dampal berdiam di Dampal, kabupaten Tolitoli, Etnis Dondo berdiam di Dondo, kabupaten Tolitoli, Etnis Pendau berdiam di kabupaten Tolitoli, dan Etnis Dampelas berdiam di kabupaten Donggala.

Selain 13 kelompok etnis, ada beberapa suku bangsa hidup di daerah pegunungan, seperti suku Da'a di Donggala, suku Wana di Morowali, suku Seasea dan Suku Ta' di Banggai, dan suku Daya di Buol Tolitoli. Meskipun masyarakat Sulawesi Tengah memiliki sekitar 22 bahasa yang saling berbeda antara suku yang satu dengan yang lainnya, namun masyarakat dapat berkomunikasi satu sama lain menggunakan bahasa Melayu dan/atau Bahasa Indonesia sebagai bahasa nasional dan bahasa pengantar sehari-hari. Selain penduduk asli, Sulawesi Tengah dihuni pula oleh transmigran seperti dari Bali, Jawa, Nusa Tenggara Barat, dan Nusa Tenggara Timur. Suku yang juga banyak mendiami wilayah Sulawesi Tengah adalah Bugis, Makasar, dan Toraja serta etnis lainnya di Indonesia sejak awal abad ke-19 dan sudah membaur. Jumlah penduduk di daerah ini sekitar 2.128.000 jiwa yang mayoritas beragama Islam; lainnya Kristen, Hindu, dan Budha. Tingkat toleransi beragama sangat tinggi dan semangat gotong-royong yang kuat merupakan bagian dari kehidupan masyarakat. Penduduk Sulawesi Tengah sebagian besar memeluk agama Islam. Tercatat $72,36 \%$ penduduknya memeluk agama Islam, 24,51\% memeluk agama Kristen, dan $3,13 \%$ memeluk agama Hindu serta Budha. Islam disebarkan di Sulawesi

130 Sumber: BPS, 2010. 
Tengah oleh Datuk Karamah, seorang ulama dari Sumatera Barat.

\section{Politik Lokal dan Permesta di Sulawesi Tengah}

Kasus politik lokal wilayah Sulawesi Tengah dipengaruhi oleh kasus politik yang terjadi di Sulawesi Selatan Tenggara dan Sulawesi Utara Tengah. Harvey (1989a; 1989b) dan Leirisa (1997) telah membahas kasus Permesta sebagai gerakan politik lokal yang menginginkan otonomi sejak tahun 1957 di Pulau Sulawesi (baca: Sulawesi Selatan dan Sulawesi Utara). Karya historiografi mengenai "Permesta" yang ditulis oleh Harvey dan Leirissa belum dan tidak menjelaskan pertentangan orangorang Permesta dengan anggota GPST di Kabupaten Poso Sulawesi Tengah. ${ }^{131}$ Karya Harvey yang berjudul "PRRI/ Permesta: Pemberontakan Setengah Hati" diulas dengan rapih dan sistematis menurut kaidah penelitian sejarah. Pembahasan Harvey memulainya dengan keadaan politik di Sulawesi Selatan Tenggara termasuk Keadaan Politik Sulawesi Utara Tengah, namun secara khusus keadaan politik di Sulawesi Selatan. Kemudian, kronologi perkembangan gerakan Permesta hingga berahirnya serta pasca gerakan Permesta. Kajian Harvey mengenai PRRI/Permesta tuntas karena melakukan studi arsip secara memadai di Jakarta dan di Arsip Makassar mengenai Permesta. Namun, salah satu kekurangannya tidak ada dalam buku itu pembahasan mengenai kelompok yang menentang Permesta selain militer RI, tetapi karena substansi kajiannya hanya tertuju pada anatomi gerakan PRRI/ Permesta. Penelitian standar PRRI/ Permesta yang dilakukan oleh Harvey ini sesungguhnya diharuskan untuk membahas GPST sebagai sebuah organisasi yang melawan secara sistematis Permesta di Kabupaten Poso Sulawesi Tengah.

Almarhum Leirisa ${ }^{132}$ juga telah melakukan penelitian mengenai PRRI/

131 Haliadi, GERAKAN PEMUDA SULAWESI TENGAH DI POSO: Antara Otonomi dan Pemikiran Kekuasaan Lokal, dipresentasikan pada Konferensi Nasional Sejarah IX dan Kongres Masyarakat Sejarawan Indonesia oleh Direktorat Jenderal Sejarah dan Purbakala Direktorat Geografi Sejarah Kementerian Kebudayaan dan Pariwisata RI di Jakarta, tanggal 5-8 Juli 2011. Baca juga: Haliadi dkk., Gerakan Pemuda Sulawesi Tengah (GPST) di Poso 1957-1963: Perjuangan anti Permesta dan Pembentukan Provinsi Sulawesi Tengah, Yogyakarta: Ombak, 2007.

132 Buku Leirissa secara lengkap: PRRI Permesta Strategi Membangun Indonesia Tanpa Komunis yang terbit di Jakarta oleh penerbit Pustaka Utama Grafiti pada tahun 1991/1997. 
Permesta, namun dalam hasil laporan atau bukunya belum membahas GPST di Kabupaten Poso sebagai organisasi yang melawan Permesta. Kebetulan penulis ini memiliki latar-belakang penelitian yang banyak mengenai Sulawesi Utara, namun dalam bukunya tentang Permesta tidak banyak melihat keadaan Sulawesi Tengah sebagai bagian dari Provinsi Sulawesi Utara Tengah pada waktu itu. Buku ini kaya akan arsip-arsip PRRI/Permesta di Sulawesi Utara, namun sayang keadaan Permesta di Sulawesi Tengah dalam hubungannya dengan GPST tidak dimasukan. Kekurangan ini yang nantinya akan dibahas dan fokus pada GPST di Kabupaten Poso Sulawesi Tengah.

Namun, pertanyaan yang menarik adalah apakah permesta mendapatkan tantangan di tingkat lokal sebagai bentuk ketidaksetujuan anak daerah terhadap gerakan tersebut? Pertanyaan ini belum banyak dijawab dalam dua kajian tersebut, sehingga perlu kiranya merekonstruksi kembali sekaligus mengembangkan analisis "pemikiran pelaku" dalam politik lokal di Sulawesi Tengah untuk menyoroti "Gerakan Pembentukan Provinsi Sulawesi Tengah" pada tahun 1950 hingga 1964 sebagai bentuk reaksi lokal terhadap gerakan Permesta di Sulawesi Utara.
Wilayah Sulawesi Tengah pada tahun 1950-an dikendalikan secara politik dari Manado sebagai ibukota Provinsi Sulawesi Utara Tengah. Keadaan aparat pemerintahan yang belum memadai waktu itu sehingga mulai dari aturan ketatanegaraan maupun pelaksanaanadministrasipemerintahan secara praktis belum terlaksana secara memadai. Terutama pada tahun 19571960, keadaan militer di Sulawesi Tengah dapat dikatakan tidak stabil atau belum terkoordinir secara memadai. Keadaan itu kelihatan penataan Kodam Sulawesi Utara/Tengah yang dipengaruhi oleh PRRI/Permesta pada bulan Juni 1957, adanya pembelotan Panglima KDM-SUT Letkol. D.J. Somba yang "menyatakan dukungannya kepada PRRI dan menyatakan diri lepas dari Republik Indonesia."133

Permesta atau Perjuangan Semesta merupakan gerakan yang menuntut otonomi daerah yang diproklamasikan di Sulawesi Selatan pada tanggal 2 Maret 1957 oleh 51 tokoh politik, birokrat, dan militer termasuk pengusaha yang tersebar dari Pulau Sulawesi. Pada bulan Juni 1957, Sumual pindah ke Minahasa dan bersama Somba melakukan Konferensi Kerja Permesta di Gorontalo sehingga pada tanggal 20 Juni 1957 secara sepihak mengumumkan pembentukan Provinsi

133 Elyas Joseph (ed), Lintasan Perjuangan dan Pengabdian Prajurit Kodam VII Wirabuana Makassar: Pembinaan Mental Kodam VII Wirabuana, 1994, hal. 88. 
Sulawesi Utara dan mengangkat Gubernurnya H.D. Manoppo orang Bolaang Mongondow. Hal itu merupakan perwujudan awal tujuan gerakan Permesta berupa otonomi daerah Sulawesi Utara atas Sulawesi Selatan.

Kekuasaan Permesta selain di Sulawesi Utara juga di wilayah Sulawesi Tengah termasuk wilayah Kabupaten Poso setelah Sumual memindahkan kekuasaan Permesta ke Sulawesi Utara pada pertengahan bulan Juni 1957. Sumual pada bulan tersebut memindahkan Batalyon 702 yang kebanyakan memiliki anggota dari Minahasa termasuk Dee Gerungan, Eddy Gagola, Lendy Tumbelaka, John Ottay ${ }^{134}$ dari Makassar ke Sulawesi Utara dengan memilih markas besar Permesta di Kinilow. Pada tanggal 20 Juni 1957 Sumual menyatukan Sulawesi Utara Tengah yang terpisah dari Sulawesi Selatan Tenggara. Provinsi Sulawesi Utara Tengah mengangkat Manoppo sebagai Gubernur. Wilayah Sulawesi Utara Tengah secara administratif dibagi kedalam tujuh Kabupaten dan Kota Madya, yakni: (i) Kota Madya Manado, (ii) Kabupaten Minahasa, (iii) Kabupaten Gorontalo, (iv) Kabupaten Bolaang Mongondow, (v)
Kabupaten Sangir Talaud, (vi) Kabupaten Sulawesi Tengah, dan (vii) Kabupaten Tanah Toraja. ${ }^{135}$ Kabupaten Sulawesi Tengah waktu itu hingga munculnya GPST dipimpin oleh masing-masing Kepala Daerah pertama R.M. Pusadan dan sejak 1952 Bupati Poso antara lain: Abdul Latif Daeng Masikki 1952-1954, Alimuddin Daeng Matiro 1954-1956, Djafar Lapasere 1956-1957, S. Kabo 1957-1959.

Bukti solidaritas pembangkangan PRRI/Permesta diperlihatkan dalam organisasi militer yang dibentuk oleh Sumual dan kawan-kawan. Kasad Permesta dipimpin langsung oleh Sumual dengan membawahi Angkatan Darat Revolusi (ADREV), Angkatan Udara Revolusi (AUREV) di bawah Laksamana Muda/TII Muharto, Angkatan Laut Revolusi (AUREV) dipimpin oleh Kapten Laut L.D. Pesik, dan Polisi Revolusi (POLREV) dipimpin oleh Letkol W.H. Korompis. Kasad membawahi empat Komando Daerah Pertempuran (KDP). KDP-1 mewilayahi Maluku, Irian Barat, dan Sangir Talaud. KDP-2 mewilayahi Minahasa. KDP-3 mewilayahi Bolaang Mongondow. KDP-4 dipimpin oleh Mayor D. Gerungan mewilayahi Daerah Sulawesi Tengah. ${ }^{136}$

134 Barbara Sillars Harvey, Pemberontakan Kahar Muzakkar dari Tradisi ke DI/TII. Jakarta: Grafiti Pers, 1989, hal. 282.

135 R.Z. Leirissa, PRRI Permesta: Strategi Membangun Indonesia tanpa Komunis. Jakarta: Pustaka Utama Grafiti, 1991/1997, hal. 110-111.

136 Kodam VII Wirabuana, Lintasan Perjuangan dan Pengabdian Prajurit Kodam VII Wirabuana. Ujung Pandang: Pembinaan Mental Kodan VII Wirabuana, 1994, hal. 90-91. 
Kekuatan militer PRRI/Permesta di Sulawesi Tengah terdiri atas Batalyon 719 dan Brimob 5490. Invasi militer atas daerah Sulawesi Tengah dilakukan oleh D.J. Somba dengan nama Ekspedisi Jakarta II langsung menguasai Parigi pada 22 Mei 1958 namun dapat dipukul oleh pasukan Kapten Frans Karangan hingga mereka jalan kaki ke Sulawesi Utara. Militer RI melakukan penumpasan dengan nama opersi Merdeka oleh Frans Karangan, operasi Sapta Marga II oleh Letkol Inf. Soemarsono dari pasukan Yon 501/Brawijaya, Yon 601/Tanjung Pura, dan Kompi Khusus Koandait dengan operasi di Sulawesi Tengah antara lain Donggala, Palu, Parigi, Tawaeli, Toboli, Kulawi, Bada, Poso, Taipa, dan Tentena. Operasi ini membuat Yon 501/Brawijaya membuat gesekan dengan pemuda Poso yang tergabung dalam GPST. Gesekan itu yang menyebabkan wafatnya pemimpin-pemimpin GPST di Kabupaten Poso.

Pada masa Permesta, Poso sebagai bagian dari Kabupaten Sulawesi Tengah dikuasai oleh pasukan Per- mesta. Isu Permesta hanya berada di kalangan militer yang bertugas pada saat itu. Permesta di daerah-daerah digalakkan oleh pemuda-pemuda proPermesta dengan nama Komando Pemuda Permesta (KoP2) sedangkan lawannya adalah pemuda pro-Negara Kesatuan Republik Indonesia (NKRI). Organisasi lawan Ko2P di wilayah Poso adalah Gerakan Pemuda Sulawesi Tengah (GPST) yang dipimpin oleh Asa Bungkundapu. Militer Permesta menguasai Sulawesi Tengah yang dipimpin oleh Somba dengan menguasai Parigi dan termasuk Poso, sedangkan di Kabupaten Poso khusus dipimpin oleh Pallar. Permesta menurut hitungan Tentara Nasional Indonesia (TNI) waktu itu memiliki jumlah personil kurang lebih 6000 personil. ${ }^{137}$

Gerakan Pemuda Sulawesi Tengah yang disingkat GPST merupakan gerakan yang dipimpin oleh Asa Bungkundapu ${ }^{138}$ dalam menuntut Provinsi Sulawesi Tengah yang otonom dan resimen induk di Sulawesi Tengah yang dipegang oleh putera-putera daerah Sulawesi Tengah. Gerakan itu dimulai sejak tanggal 5

137 B. E. Matindas dan Bert Supit, Ventje Sumual Menatap Hanya ke Depan: Biografi Seorang Patriot, Filsuf, Gembong Pemberontak. Jakarta: Bina Insani, 1998, hal. 313.

138 Asa Bungkudapu lahir pada tanggal 9 Maret 1925, menjadi pegawai perpajakan di Poso-di awal tahun 1950 mengorganisir pemuda-pemuda Poso dalam organisasi SERBU yang bertugas membantu Polisi untuk menjaga keamanan dari kelompok yang menamakan diri Laskar Merah Putih yang datang ke Poso untuk melucuti persenjataan kepolisian. Ketua Umum GPST 1957 1960 . 
Desember $1957^{139}$ ditandai dengan pelarian para pemuda ke hutan untuk menyusun strategis hingga terbunuhnya 15 orang pimpinan GPST pada tanggal 10 Desember 1960. ${ }^{140}$ GPST Kabupaten Poso melakukan gerakan perlawanan secara total terhadap kekuasaan Permesta di Sulawesi Tengah, terutama di wilayah Kabupaten Poso mulai dari Poso, Tentena, Mori, Kolonodale, Bungku, Tojo, Ampana, hingga Banggai.

Pada tahun 1957 keadaan sosial kemasyarakatan di wilayah Sulawesi Tengah terutama Kabupaten Poso sesungguhnya dalam keadaan yang dapat dikatakan resah. Keresahan itu disebabkan oleh dua gerakan besar di Pulau Sulawesi, yaitu Gerakan DI/TII yang datangnya dari bagian Selatan Pulau Sulawesi dan gerakan Permesta yang datangnya dari Sulawesi Utara. Menurut Zainuddin Bolong bahwa gerakan DI/TII yang masuk ke Sulawesi Tengah terdiri atas dua jalur, yakni Jalur pertama, daerah Mamuju di Pantai Barat Sulawesi Tengah (Selat Makassar) di Kecamatan Pasang Kayu yang berbatasan dengan Kecamatan
Banawa Sulawesi Tengah dan langsung ke Utara di Kecamatan DampelasSojol sampai masuk ke wilayah Kabupaten Buol Tolitoli. Gerombolan DI/TII tersebut dipimpin oleh M. Nur Rasyid. Jalur kedua, berasal dari dataran tinggi bagian tengah dari Tanah Toraja ke pedalaman Poso dan terus ke daerah Luwuk Banggai di bawah pimpinan M. Amin Larekeng. Kekuatan DI/TII yang beroperasi di Sulawesi Tengah diperkirakan mencapai 1.000 hingga 1.500 personil. $\mathrm{M}$. Nur Rasyid beroperasi di wilayah Donggala dan daerah Tolitoli, sedangkan M. Amin Larekeng beroperasi di wilayah Poso dan wilayah Luwuk Banggai.

Gerakan Pemuda Sulawesi Tengah sebagai salah satu bentuk reaksi lokal Sulawesi Tengah terhadap gerakan Permesta atas nama lokal yang menjadi cikal bakal terbentuknya Provinsi Sulawesi Tengah pada tahun 1964 sebagai salah satu Provinsi yang mekar dari Provinsi Sulawesi Utara Tengah. Gerakan Pemuda Sulawesi Tengah berpusat di Poso yang melibatkan kurang lebih 20.000

139 Ef. Toripah, "Sedikit tentang Watak dan Perjuangan GPST di Sulawesi Tengah, dalam Arsip Provi nsi Sulawesi (APS), nomor registrasi: 236; baca juga: "Ikatan Keluga Sulawesi Tengah Desak Segera Dibentuknya Resimen Induk untuk Daerah Sulawesi Tengah: Pemuda dan Rakyat Sulawesi Tengah berdiri di belakang Pemerintah Pusat," Berita Antara, Jum'at, 3 Januari 1958, nomor: $3 / \mathrm{A}$

140 Naskah sejarah singkat Terjadinya Pembunuhan 15 Orang Pimpinan dan atau Anggota Pasukan Partisan GPST pada tanggal 10 Desember 1960 di Poso. 
pemuda yang terbagi dalam 10 divisi/ sektor untuk menghalau Permesta dari Utara dan DI/TII dari Selatan. Keanggotaan GPST di Sulawesi Tengah hampir semua etnis yang berada di Poso dan sekitarnya. Perjuangan mengusir Permesta dari Sulawesi Tengah berlangsung sejak tanggal 5 Desember 1957 hingga 14 Juli 1958 berhasil menguasai Poso dan mengusir Permesta dari wilayah itu. Keberhasilan GPST membuktikan bahwa pemuda Sulawesi Tengah berhasil memperjuangkan apa yang dicita-citakannya, yakni Provinsi yang otonom dan resimen induk di Sulawesi Tengah sebagaimana tercantum dalam siaran kilat yang dikeluarkan sejak mereka ke hutan di wilayah Poso dan sekitarnya:

"KAMI, PUTERA DAN PUTERI SULAWESI TENGAH, DENGAN INI MEMISAHKAN DIRI DARI HALAYAK RAMAI, MENUNTUT DAERAH TINGKAT I (SATU) DAN RESIMEN INDUK YANG TERDIRI DARI PUTERA DAN PUTERI SULAWESI TENGAH. POSO, 5 DESEMBER 1957. SEKALI 5 DESEMBER, TETAP 5 DESEMBER" ${ }_{141}$

\section{Pemikiran Politik Lokal Sulawesi Tengah}

Semangat dari dua kabupaten otonom di Sulawesi Tengah, yakni Kabupaten Poso dan Kabupaten Donggala, tersebut menjadi semacam spirit masyarakat Sulawesi Tengah untuk memperjuangkan Provinsi Sulawesi Tengah dari cengkeraman Sulawesi Utara yang agak militan (baca: PERMESTA) waktu itu. Perjuangan masyarakat Sulawesi Tengah dalam pembentukan Provinsi Sulawesi Tengah dilakukan secara bersama-sama secara politik dan juga militan dengan prinsip-prinsip masingmasing yang diperlihatkan dalam konsepsi yang diajukan masingmasing sebagai wujud dari pengalaman kolektif para tokoh bagian Tengah Pulau Sulawesi. Pengalaman atau memori kolektif tersebut diajukan dalam beberapa konsepsi, seperti: Konsepsi Residen Manoppo, Konsepsi Toraja Raya, Konsepsi Makassar, Konsepsi Zakaria Imban, Konsepsi Tobing, Konsepsi Ngitung, Konsepsi Provinsi Tomini Raya, dan Konsepsi Mahasiswa Sulteng.

Pertama, Konsepsi Residen Manoppo. Konsepsi Provinsi Sulawesi Tengah yang wilayahnya meliputi

141 Wawancara dengan Nico Pelima dan Tonigi; baca juga karya Aser Tandapai (GPST: Gerakan Setengah Hati, belum diterbitkan, 2008). 
Kabupaten Donggala, Kabupaten Poso, dan Kabupaten Gorontalo. Konsep ini dikenal dengan nama "Konsepsi Residen Manoppo" dan mendapat dukungan dari DPRD Donggala pada tahun $1954 .{ }^{142}$ Konsepsi ini tentu saja dilakukan dari Manado dengan tidak terlalu banyak memperhatikan kasuskasus di Sulawesi Tengah secara otonom.

Kedua, Konsepsi Toraja Raya. Konsepsi Provinsi Sulawesi Tengah yang wilayahnya meliputi Kabupaten Donggala, Kabupaten Poso, dan Kabupaten Tanah Toraja. Konsepsi ini terkenal dengan nama "Konsepsi Tumakaka-Tambing" atau "Konsepsi Toraja Raya" Konsepsi ini didukung oleh penempatan militer pimpinan Frans Karangan di Palu dan disinyalir bahwa GPST berhubungan dengan konsepsi ini. Tumakaka juga adalah seorang anggota DPR Pusat sehingga segala urusan di Pusat atau di Jakarta, dia yang selalu melakukannya. Demikian juga dengan Tambing seorang kelahiran Toraja yang menjadi anggota DPR Pusat waktu itu yang getol mempejuangkan terbentuknya Provinsi Sulawesi Tengah di Jakarta.

Ketiga, Konsepsi Makassar. Konsepsi Provinsi Sulawesi Tengah yang wilayahnya meliputi Kabupaten
Donggala, Kabupaten Poso, dan Kabupaten Luwu Palopo. Konsepsi ini dikenal dengan nama Konsepsi "Hamid Syahid Arsyad Pane" atau "Konsepsi Makassar" yang berdasarkan hak historis dari Kerajaan Luwu-Palopo. Konsepsi ini dilakukan dari Makassar sehingga perspektif atau pandangan terhadap Sulawesi Tengah selalu dihubungkan dengan keberadaan konstalasi politik di Makassar sebagai pusat kegiatan anak sekolah atau anak-anak daerah yang melakukan studi di Makassar.

Keempat, Konsepsi Zakaria Imban. Konsepsi Provinsi Sulawesi Tengah yang wilayahnya meliputi Kabupaten Donggala, Kabupaten Poso, Kabupaten Gorontalo, dan Kabupaten Bolaang Mongondow. Konsepsi ini biasa dikenal dengan nama, "Konsepsi Zakaria Imban" (anggota DPR-GR asal Bolaang Mongondow). Konsepsi ini juga dilakukan dari Jakarta untuk mengimbangi konsepsi dari Manado dan dari Sulawesi Tengah, namun tujuan utamanya adalah memasukan Bolaang Mongondow dalam wilayah Sulawesi Tengah dan keluar dari wilayah Sulawesi Utara atau keluar dari Manado.

Kelima, Konsepsi Tobing. Konsepsi Provinsi Sulawesi Tengah yang

142 Sutrisno Kutoyo, dkk., Sejarah Daerah Sulawesi Tengah. Jakarta: Pemda Sulteng dan Dinas Kebudayaan dan Pariwisata, 2005, hal. 247-248. 
wilayahnya meliputi Kabupaten Donggala, Kabupaten Poso, Kabupaten Tana Toraja dan Mamuju. Konsepsi ini dikemukakan oleh bekas Menteri Antar Daerah dalam Kabinet Karya oleh Dr. Tobing.

Keenam, Konsepsi Ngitung. Konsepsi Provinsi Sulawesi Tengah yang wilayahnya meliputi daerah Luwuk/Banggai, Daerah Kolonodale, Daerah Bungku, dan Daerah Kendari. Konsepsi ini kemudian berubah menjadi "konsepsi Ngitung" (Mantan Kepala Daerah Poso). Ngitung merupakan seorang putra kelahiran Bungku yang menjabat sebagai Bupati Kepala Daerah Poso periode 1960-1962.

\section{Ketujuh, Konsepsi Provinsi} Tomini Raya. Konsepsi Provinsi Sulawesi Tengah yang wilayahnya meliputi daerah Tolitoli, daerah Buol, Kepulauan Una-Una, Gorontalo, dan Bolaang Mongondow. Konsepsi ini kemudian berubah menjadi Konsepsi "Provinsi Tomini Raya," yang dikenal pula sebagai "Konsepsi Nani Wartabone" (Mantan Residen Koordinator Sulawesi Utara). Nani Wartabone melakukan aktivitas politik dan perjuangan di wilayah Gorontalo dan sekitarnya sehingga diangkat menjadi pahlawan nasional bagi Gorontalo.

Kedelapan, Konsepsi Mahasiswa Sulteng. Konsepsi Provinsi Sulawesi Tengah yang wilayahnya hanya meliputi Kabupaten Donggala dan Kabupaten Poso. Konsepsi ini dikenal dengan nama "Konsepsi Mahasiswa
Sulteng" atau konsepsi "Rusdi ToanaMene Lamakarate." Rusdi Toana merupakan tokoh masyarakat dan intelektual serta aktif sebagai wartawan di Sulawesi Tengah. Mene Lamakarate merupakan seorang bangsawan Kaili dari Biromaru. Rusdi Toana merupakan tokoh Sulawesi Tengah yang aktif sebagai wartawan dalam mendirikan koran Mercusuar. Koran Mercusuar merupakan nama koran awal yang diketahui secara umum di Sulawesi Tengah yang dirintis oleh Rusdy Toana. Koran Mercusuar diterbitkan pada 1 September 1962 hingga sekarang. Pada awalnya pimpinan koran ini dipegang oleh Rusdy Toana, baik sebagai pemimpin umum maupun pemimpin redaksi. Wakilnya dipegang oleh Tri Putra Toana, General Manager dipegang oleh Joko Intarto. Rusdy Toana selain sebagai tokoh pers yang tertua di Palu Sulawesi Tengah, beliau juga tokoh Muhammadiyah Provinsi Sulawesi Tengah. Rusdy Toana juga pernah menjabat sebagai Rektor Universitas Muhammadiyah di Kota Palu. Perjuangan Rusdy Toana sekarang sudah dilanjutkan oleh putraputranya dengan mendirikan Koran Mercusuar di Kota Palu. Salah satu pengakuan tokoh pembentukan terbentuknya Provinsi Sulawesi Tengah telah dimuat dalam kesimpulan sarasehan mengenai sejarah dan pembangunan. Hal itu dikemukakan bahwa munculnya Gerakan Pemuda Sulawesi Tengah (GPST) sebagai berikut ini.

"Boleh dikata di tahun 1957 itulah merupakan puncak 
dari perjuangan pergolakan perjuangan penuntutan Provinsi Sulawesi Tengah dimana di Poso pada Desember 1957 dibentuk "Gerakan Pemuda Sulawesi Tengah" (GPST) di bawah pimpinan Asa Bungkundapu dan kawan-kawan, yang menentang gerakan Permesta.

Saya katakan bahwa di tahun 1957 itu merupakan puncak karena di tahun itulah merupakan puncak pertarungan 8 (delapan) macam konsepsi mengenai Provinsi Sulawesi Tengah itu, dimana Pemerintah Pusat sulit menetapkan keputusannya."143

Kutipan tersebut merupakan kutipan dari pelaku yang mengemukakan konsepsi kedelapan yang menang dari upaya pembentukan Provinsi Sulawesi Tengah.

\section{Terbentuknya Provinsi Sulawesi Tengah}

Perjuangan pembentukan Provinsi Sulawesi Tengah sesungguhnya telah diperjuangkan sejak tahun 1948, yakni sejak raja-raja di wilayah ini sepakat mengintegrasikan kerajaannya kepada Republik Indonesia. Mengikuti pola pikir yang dikemukakan oleh Hedy Shri Ahimsa-Putra ${ }^{144}$ dan Nasikun bahwa integrasi sosial biasanya tidak pernah dapat dicapai dengan sempurna, namun dalam kenyataan sejarah Sulawesi Tengah pasca kolonial dapat diperhatikan adanya integrasi awal menuju terbentuknya Provinsi Sulawesi Tengah. Integrasi sebagai upaya awal perjuangan pembentukan Provinsi Sulawesi Tengah terjadi pada tahun 1948. Peristiwa tahun 1948 berhasil memperjuangan UU No. 33 tahun 1952. Keluarnya Undang-Undang Nomor 33 tahun 1952 menjadi momentum penting terbentuknya Kabupaten Donggala dan Kabupaten Poso di wilayah Sulawesi Tengah yang di dalamnya menciptakan tokoh-tokoh politik yang berusaha membentuk Provinsi Sulawesi Tengah yang baru dari provinsi induk Provinsi Sulawesi Utara Tengah.

Pada tanggal 27 sampai tanggal 30 Nopember 1948 diadakan pertemuan raja-raja Sulawesi Tengah yang biasa dikenal dengan nama "Muktamar Raja-Raja se-Sulawesi Tengah di Parigi". Pada pertemuan itu dihadiri oleh: Raja Poso (W.L. Talasa), Raja

143 Rusdi Toana dan Abd. Karim Mbouw, Mengungkap Perjuangan Rakyat Sulawesi Tengah di Arena Sejarah Bangsa Indonesia, yang diselenggarakan oleh Panitia Sarasehan Sejarah dan Pembangunan Sulteng, Fakultas Sospol UNTAD (Cabang UNHAS) di Palu pada bulan April 1980, hal. 28.

144 Heddy Shri Ahimsa Putra, "Hambatan Budaya dalam Integrasi Politik: Sulawesi Selatan pada Abad Ke-19," Buletin Antropoplogi, No. 16 tahun VII/1991. 
Tojo (Muslaini), Raja Una-Una (Lasahido), Raja Bungku (Abd. Rabbie), Raja Tavaeli (Lamakampali), Raja Moutong (Tombolotutu), Raja Parigi (Tagunu), Raja Mori (Rumampuo), Raja Sigi-Dolo (Lamakarate), Raja Banggai (S.A. Amir), Raja Palu (Tjatjo Ijazah), Raja Lore (S. Kabo), Raja Banawa (L. Lamarauna), Raja Kulawi (W. Djiloi), dan Vorzitter Zelfbestuurscommissie Tolitoli (R.M.Pusadan). Pertemuan itu menghasilkan: Penetapan Undang-Undang Dasar Sulawesi Tengah yang ditetapkan pada tanggal 2 Desmeber 1948, kemudian disahkan oleh Residen Manado pada tanggal 25 Januari 1949 nomor R.21/1/4. Mereka sepakat untuk keluar dari Negara Indonesia Timur (NIT) dan tetap bergabung dengan Negara Kesatuan Republik Indonesia (NKRI). Keputusan itu antara lain: Pertama, bentuk pemerintahan yang ada di Sulawesi Tengah diarahkan pada corak otonom (setingkat daerah tingkat II), Kedua, mengangkat R.M. Pusadan sebagai Kepala Daerah Sulawesi Tengah yang pertama. ${ }^{145}$

Tokoh-tokoh yang aktif di dua Kabupaten tersebut memperjuangkan pembentukan Dewan Perwakilan Rakyat Daerah Sementara (DPRDS) pada tahun 1951. Pada tahun 1951 dikeluarkan Peraturan Pemerintah nomor 56 tahun 1951 untuk membagi dua Daerah Sulawesi Tengah menjadi dua wilayah otonom setingkat Kabupaten, yakni: Kabupaten Poso dengan ibukota di Poso dan Kabupaten Donggala dengan ibukota di Palu. Langkah strategis yang diambil oleh Sudiro selaku Gubernur Sulawesi Utara Tengah dikeluarkan Peraturan Pemerintah Nomor 56 tahun 1951 tentang Pembekuan DPRD dan DPD Sulawesi Selatan. Realisasi dari pemenuhan kemauan raja-raja dan masyarakat Sulawesi Tengah, Gubernur Sudiro mengeluarkan Surat Keputusan nomor 33 tanggal 25 Oktober 1951 dan dirubah tanggal 30 April 1952 dengan membagi Sulawesi Tengah menjadi dua Kabupaten, yakni Kabupaten Poso dan Kabupaten Donggala. Sesudah Surat Keputusan (SK) Gubernur Sulawesi Utara Tengah diterima, Dewan Perwakilan Rakyat Daerah Sulawesi Tengah yang dipimpin oleh A.Y. Binol dalam sidangnya pada tanggal 16 Nopember 1951, memutuskan dengan suara bulat dan menyetujui pembagian daerah

145 Haliadi, Historiografi Lokal dan Nasionalisme di Sulawesi Tengah: Menuju Terbentuknya Nation Character Building di Daerah, Makalah diajukan sebagai bahan FGD yang bertema "Pembentukan Badan Pengkajian dan Pemasyarakatan Empat Pilar Kehidupan Bernegara, Urgensi dan Relevansinya dalam Mewujudkan Nation Character Building," yang diadakan oleh Kerjasama UNTAD dengan MPR RI di SwissBel Hotel, tanggal 26 Juli 2011. 
Sulawesi Tengah menjadi dua daerah, yaitu Poso dengan ibukota Poso dan Donggala dengan ibukota Palu.

Berkenaan dengan sidangnya waktu itu juga DPRD Sulawesi Tengah mengeluarkan suatu Pernyataan yang memutuskan: menyatakan pembekuan DPRD Sementara Daerah Sulawesi Tengah dan Dewan Pemerintahan Daerahnya (DPD). Menyerahkan tugas kekuasaan kepada Gubernur Sulawesi untuk dijalankan dengan dibantu oleh suatu Badan Penasehat yang diangkat oleh Menteri Dalam Negeri atas dasar dari Gubernur Sulawesi. ${ }^{146}$ Pernyataan Gubernur Sulawesi Utara Tengah tersebut disahkan dengan surat keputusan nomor 118 tanggal 4 Maret 1952, karena Sulawesi Tengah sudah terbagi dua sehingga Kepala Daerah Sulawesi Tengah R.M. Pusadan menyerahkan Kepala Pemerintah daerah Poso dan Donggala. Kabupaten Poso dijabat oleh Abd. Latif Dg. Masikki, dan Kabupaten Donggala dijabat oleh Intje Naim. Anggota DPRD-S daerah Sulawesi Tengah yang terbentuk pada saat itu dapat diperhatikan pada tabel berikut ini:
Tabel 1 Susunan DPRD-S

Sulawesi Tengah Tahun 1951

\begin{tabular}{|l|l|l|}
\hline NO & NAMA & UTUSAN \\
\hline 1 & ANDI RAGA PETALOLO & DONGGALA \\
\hline 2 & BASTARI LABORAHIMA & UNA-UNA \\
\hline 3 & BUSTAMAN & DONGGALA \\
\hline 4 & DG. MANGERA & KALEKE \\
\hline 5 & Dr. W TUMANAKENG & WANITA PALU \\
\hline 6 & E. KANSIL & LUWUK \\
\hline 7 & H. HUSIN & BUNGKU \\
\hline 8 & J. MAGIDO & POSO \\
\hline 9 & JONDI MARANUA & TAWAELI \\
\hline 10 & LASUPU & AMPANA \\
\hline 11 & LUMENTUT & PEMUDA POSO \\
\hline 12 & M. JUSUF & KETUA MUDA \\
\hline 13 & MONOARFA & PNI POSO \\
\hline 14 & SUNGKA MARUNDU & KOLONODALE \\
\hline 15 & SUNUSI PATIMBANG & PALU \\
\hline 16 & UMAR SAID & TOLITOLI \\
\hline 17 & USMAN SOANI & TOLITOLI \\
\hline \hline
\end{tabular}

Sumber: Arsip Provinsi Sulawesi Nomor Registrasi 161 dan 222.

Dinamika Politik lokal di tingkat bawah juga memiliki perkembangan yang menarik. Contoh di DPRD Sementara Kabupaten Donggala di Palu sejaktahun 1954 sudahmemperlihatkan aktivitas yang memadai. Merujuk Arsip Provinsi Sulawesi yang menjadi anggota DPRD-S Donggala waktu itu tercatat sebanyak 19 orang, antara lain: Djafar Lapasere sebagai Ketua dan Sekretarisnya M.Dj. Abdullah, dengan anggota: Is Masu, D.M. Rundalemba, Jondi Maranua, D. Pidu, Is Borahima, B. Marhum, Usman Atja,

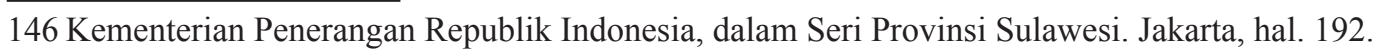


D. Pawara, Nj. Kairupan Malonda, W.F. Makapedua, A.P.Tagunu, Abd. Marzuli, A.A. Tombolotutu, dan M.S. Patimbang. ${ }^{147}$ Pada 8 April 1954, mereka melakukan sidang mengenai pandangan DPRD-S Donggala mengenai upaya dan usaha DPD Donggala. Salah satu contoh dinamika pandangan politik dari pembentukan Kabupaten Donggala yang diarahkan kepada pembangunan adalah pandangan anggota yang bernama Jondi Maranua yang menyatakan bahwa:

"Pemerintah daerah ini menurut hemat saya adalah memakai politik "Burung Unta"; sekali lagi saya katakan, memakai politik burung unta, sebab segala motifmotif yang diutarakan itu hanya berdasarkan laporan-laporan belaka. Pemerintah (DPD) asal duduk dalam otonyakesanakemari tetapi tidak mempergunakan matanya kekiri dan kekanan, apakah itu kebutuhan-kebutuhan yang dibutuhi masyarakat yang diperintahnya itu. Waktu ....

Dengan terburu2 membicarakan bantuan daerah untuk menunjang modal listerik di Kota Palu, mereka terus memberi jawaban, ini ada $\mathrm{Rp} 100.000$ untuk listerik tersebut. Inilah anggapan saya politik-politik burung unta yang membunyikan kepalanya tetapi sadar ekornya dapat dilihat. Kini masyarakat sangat gelisah karena meninjau dari sudut politis, bahwa tehnis sama sekali tidak mendapat sambutan dari masyarakat. Barubaru ini saja Daerah kita berdiri membeli dua buah oto tetapi tidak pernah disinggung-singgung dalam pembicaraan DPD kemarin.

... Sampai ini hari di Tawaeli belum ada satu pun juga pembangunan rumah daerah tetapi sebagai dikatakan tadi, Palu ada sepuluh buah dan di Donggala ada dua buah, lagi sebentar mau datang pembangunan 21 buah rumah. Pernah pemerintah memberikan sebuah sekolah model bagi kami di Tawaeli, apapun telah selesai dan belum juga dapat dipergunakan hingga sekarang ini karena masih ada lagi yang dibutuhinya. Hingga kini anakanak kami masih mempergunakan gedung bekas bikinan di zaman Jepang dimana keadaannya telah sangat menghawatirkan karena telah miring.

...."148

Sementara, secara politik berdasarkan hasil pemilu 1955 di Sulawesi Tengah juga terjadi dinamika politik lokal yang menarik. Persiapan Pemilu tahun 1955 telah diatur dalam

147 Arsip Rahasia Provinsi Sulawesi Nomor Registrasi 331 helai A

148 Ibid, hal. 4 
Undang-Undang Nomor 7 tahun 1953 yang dibentuk oleh Kabinet Wilopo dari PNI pada tahun 1953. Undangundang ini merencanakan suatu Pemilihan Umum (Pemilu) di masa Orde Lama yang akan membentuk "Konstituante". Namun, hasil Pemilu 1955 berupa "lembaga konstituante" dengan "arogan" dibubarkan oleh Presiden Soekarno pada tanggal 4 Juni 1960. Riswandha Imawan sebelumnya telah menemukan bahwa daerahdaerah pada pemilu 1955 merupakan basis Partai Santri (baca: Partai Islam), yakni Sumsel, Kalsel, dan Sulteng yang akan nanti beralih sebagai wilayah basis Golkar pada masa Orde Baru. ${ }^{149}$ Perlu ditambahkan bahwa pada Pemilu Parlemen 1955 di wilayah Sulawesi Utara Tengah, tiga Partai mengumpul suara terbanyak secara berturut-turut adalah Masyumi $(189.198=25,1 \%)$, PSII $(173,364=$ $22,9 \%)$, Parkindo $(144.273=19,1 \%)$, PNI $(102.855=13,6 \%)$, dan PKI $(33,204=4,39 \%) .{ }^{150}$ Data-data ini memunculkan pertanyaan yang sangat menarik bahwa Sulawesi Tengah juga merupakan basis santri namun perlu ditelaah lebih dalam dan lengkap. Hal ini sesuai juga dengan kajian Alfian mengenai Pemilu 1955. ${ }^{151}$
Khusus untuk wilayah Poso, dimenangkan oleh Masyumi. Daerah Poso, perolehan suara Masyumi sebesar 53.555 jiwa dari 134.276 pemilih, menyusul Parkindo dengan suara sebesar 33.070 jiwa, baru kemudian PNI sebesar 11.271 jiwa. Daerah Donggala, persolehan suara Masyumi sebesar 49.000 jiwa dari 146.549 pemilih yang dikalahkan oleh PSII dengan perolehan sebesar 61.582 jiwa, menyusul Parkindo dengan suara sebesar 9.301 jiwa, baru kemudian PNI sebesar 8.689 jiwa. Hasil pemilu 1955 sebagai wujud terlaksananya politik Partai sudah kelihatan pada perjuangan membentuk kabupaten otonom. Sejak 15 September 1953, telah ada upaya ke arah itu yang dimulai dari Desa Kantana. Kemudian perjuangan itu dilanjutkan selama tiga tahap. Pertama, tanggal 13 Maret 1954 oleh Partai Masyumi. Tahap kedua, tanggal 10 April 1955 oleh Partai Kedaulatan Rakyat. Dan tahap ketiga, oleh empat Partai sejak tanggal 29 Mei 1955 oleh Partai Masyumi, Partai Kedaulatan Rakyat (PKR), Partai Nasional Indonesia (PNI), dan Partai Syarikat Islam Indonesia (PSII).

Pemilihan Umum (Permilu) 1955 secara lengkap di Poso dimenangkan

149 Riswandha Imawan, Peranan Organisasi Massa dan Organisasi Politik, Prisma, No.4, April 1992, hal. 37.

150 Selengkapnya tentang Pemilu 1955, lihat Feith (1999).

151 Alfian, Hasil Pemilu Tahun 1955 untuk DPR. Jakarta: Leknas, 1971, hal. 152-153. 
oleh Partai Masyumi dengan perolehan sebanyak 53.555 suara dari 134.276 jumlah pemilih lokal dari jumlah penduduk Poso yang sejumlah 255.376 jiwa. Pemenang kedua untuk wilayah Kabupaten Poso adalah Parkindo dengan perolehan suara sebanyak 33.070 suara, Pemenang Ketiga oleh PSII dengan perolehan sebanyak 21. 245 suara, menyusul PNI dengan perolehan sebanyak 11.271 suara. Pada urutan di bawah suara PNI, tercatat Nahdlatul Ulama (NU) dengan perolehan sebanyak 2.263 suara, lalu menyusul PKI 1.177 suara, dan Partai Katolik 1.345 suara. Keempat pemenang dalam pemilu di Poso pada tahun 1955 tidak perlu heran karena sejak tahun 1933, Partai Masyumi, PSII, Parkindo, dan PNI telah menunjukkan dinamika yang jelas dalam dinamika politik di Poso sejak dibentuk dan dilaksanakannya DPRD Sementara. Mereka telah melakukan kaderisasi dan selalu melakukan sosialisasi kepartaian dan sosialisasi Pemilihan umum. Hasil pemilu seperti itu merupakan hasil representasi masyarakat Poso yang tersebar di berbagai tempat, seperti Poso Kota, Poso Pesisir, Tojo Una-Una, Pamona, Lore, Mori, dan Bungku. Hasil itu adalah struktur masyarakat yang berjumlah kurang lebih 255.376 jiwa pada tahun 1955 .
Akhirnya, proses pembentukan Provinsi Sulawesi Tengah sebagai Daerah Otonom mencapai puncak pada tahun 1964. Setelah dilakukan berbagai macam pertimbangan sehingga konsepsi pemuda yang dipilih sebagai satu-satunya dasar untuk pembentukan Provinsi Sulawesi Tengah. Pemerintah Pusat mengeluarkan Peraturan Pemerintah Pengganti Undang-Undang (PERPU) nomor 2 tahun 1964 tentang Pembentukan Provinsi Sulawesi Tengah dengan ibukota di Palu. Perpu tersebut disahkan dengan Undang-Undang Nomor 13 yang diundangkan pada tanggal 23 September 1964 dan berlaku pada tanggal 1 Januari $1964^{152}$. Upacara serah terima dilakukan oleh Gubernur J.F. Tumbelaka selaku penguasa Sulawesi Utara Tengah kepada Anwar Datuk Madju Basah Nan Kuning sebagai Gubernur Provinsi Sulawesi Tengah yang pertama sesuai Surat Keputusan Pemerintah Republik Indonesia nomor 36 tahun 1964 pada tanggal 13 Pebruari $1964 . .^{153}$

Kota Palu sebagai ibukota Provinsi Sulawesi Tengah diarahkan pada interaksi Kabupaten-kabupaten Sulawesi Tengah dengan Kota Palu sebagai pusat pengembangan kebijakan di Provinsi ini. Provinsi Sulawesi Tengah terbentuk sejak tahun

152 Lembaran Negara tahun 1964 nomor 94. 153 Ibid. 
1964 dengan ibukota pemerintahan di Palu. Pada saat itu berarti Palu sebagai suatu Kota berfungsi sebagai titik simpul atas beberapa Kabupaten di Provinsi Sulawesi Tengah. Sejak Kota Palu dijadikan sebagai ibukota Provinsi Sulawesi Tengah, maka Gubernur yang berkuasa berkedudukan di Kota Palu. Sejak tahun 1964 hingga tahun 1968, Gubernur Pertama Sulawesi Tengah bernama Anwar Gelar Datoek Madjo Basah Nan Kuning yang diangkat oleh SK Presiden RI Nomor 166 tahun 1965 pada tanggal 11 Juni 1965. Kemudian, gubernur kedua bernama Kolonel Mohammad Yasin yang berkuasa dari tahun 1968 hingga tahun 1973. Mohammad Yasin diangkat oleh SK Presiden nomor 24 tahun 1968. Gubernur ketiga bernama Brigadir Jenderal A.M. Tambunan yang berkuasa dari tahun 1973 hingga tahun 1978, yang diangkat dengan SK Presiden Nomor 144/M/1973.

Gubernur keempat bernama Brigadir Jenderal Moenafri, S.H. yang berkuasa sejak tahun 1978 hingga tahun 1979 yang diangkat dengan SK Presiden nomor 191/M/1978. Gubernur kelima bernama Kolonel R.H. Eddy Djandjang Djajaatmadja yang berkuasa dari tahun 1979 hingga tahun 1980 yang diangkat dengan SK Presiden nomor 170/M/1979 sebagai Pj. GKDH. Gubernur selanjutnya atau yang keenam bernama Mayor Jenderal H. Eddy Sabara yang berkuasa tahun 1980 sebagai Pj. GKDH yang diangkat dengan SK Presiden nomor 150/M/1980. Gubernur ketujuh bernama Drs. H. Galib Lasahido yang berkuasa tahun 1981 hingga tahun 1986 yang diangkat dengan SK Presiden nomor 38/M/1981. Gubernur kedelapan bernama Abdul Aziz Lamajido yang berkuasa sejak tahun 1986 hingga tahun 1996. Selanjutnya Gubernur yang berkuasa sejak tahun 1996 bernama H.B. Paliudju yang berkuasa hingga tahun 2001 digantikan oleh Prof. Drs. Aminuddin Ponulele. ${ }^{154}$ Selanjutnya, setelah Pilkada, dimenangkan oleh H.B. Paliudju. Pada awalnya Gubernur yang berkedudukan di Kota Palu tersebut mengendalikan empat wilayah Kabupaten yang diwadahinya, yaitu Kabupaten Donggala, Kabupaten Buol Tolitoli, Kabupaten Luwuk, dan Kabupaten Poso. ${ }^{155}$

Kemudian, yang berkuasa di tingkat bawah, sebagai satu kasus, antara lain di Kabupaten Poso dan

154 Aminuddin Ponulele lahir di Palu pada tanggal 5 Juli 1939, dalam buku: M. Amir Arham, dkk., Membangun Sulawesi Tengah dengan Pola Terwujudnya Tatanan Masyarakat Madani: Kebijakan dan Obsesi H. Aminuddin Ponulele, Palu: PSKP Sulteng, 2005.

155 Syakir Mahid, dkk. (ed), Sejarah Sosial Sulawesi Tengah, Yogyakarta: Pilar Media, 2009. 
Kabupaten Donggala. Tokoh politik yang berkuasa di Poso antara lain: Bupati Poso dari tahun ke tahun hingga kini telah berjumlah 14 orang Bupati, antara lain: Abdul Latif Daeng Masikki 1952-1954, Alimuddin Daeng Mattiro 1954-1956, Djafar Lapasere 19561957, S. Kabo 1957-1959, A. Wahab 1959-1960, Ngitung 1960-1962, Drs. B.L. Sallata 1962-1966, Drs. Galib Lasahido 1966-1973, Drs. R.P.M.H. Koeswandi 1973-1983, Soegijono 1984-1989, Drs. J.W. Sarapang (Pejabat) 15 Januari-Juni 1989, Arief Patanga 1989-1999, S.H., H. Abdul Muin Pusadan, lalu digantikan oleh Piet Inkriwang. ${ }^{156}$ Bupati Poso keempat bernama S. Kabo periode 1957-1959 seorang putera daerah dari Lore. Tokoh ini merupakan bangsawan dari daerah Napu karena seorang anak raja Napu. Beliau pernah menjabat sebagai Inspektur umum Pelaksana Tugas (plt) Gubernur Muda yang membawahi: Deriktorat Ketataprajaan, Direktorat Pembinaan, dan Pengembangan Daerah, Direktorat Keamanan, dan Direktorat Politik pada masa pemerintahan M. Jasin. Setelah Bupati S. Kabo, Bupati Poso dijabat oleh A. Wahab 1959-1960, selanjutnya dijabat oleh Ngitung 1960-1962.
Drs. B.L. Sallata Bupati Poso periode 1962-1966. Dia pernah menduduki jabatan sebagai Direktorat Ketataprajaan pada masa M. Jasin sebagai Gubernur Provinsi Sulawesi Tengah. ${ }^{157}$ Pada periode jabatannya menjadi Ketua DPRD-GR Kabupaten Poso periode 1960-1964. Drs. Galib Lasahido Bupati Poso periode 19661973. Periode 1964-1966 pernah menjadi Sekretaris Daerah Provinsi Sulawesi Tengah. Pada tahun 1981 hingga tahun 1986 menjabat sebagai Gubernur Provinsi Sulawesi Tengah. ${ }^{158}$ Beliau menerima Gubernur itu sebagai wujud kepercayaan rakyat dan pemerintah secara utuh akibat dari kesabaran, keikhlasan, kejujuran, ketekunan, dan ketakwaannya. Beliau merupakan bangsawan dari Togean Kabupaten Tojo Una-Una. Drs. R.P.M.H. Koeswandi Bupati Poso periode 1973-1983. Dia lahir di Madura Sumenep pada tanggal 23 April 1930. Beliau berlatar-belakang seorang militer yang mengikuti pendidikan umum di Jurusan Civic Hukum Sarjana Muda di FKIS IKIP Manado di Poso. Karir militernya dilalui dari Shinan Se in Joseisjo di Singapura tahun 1943-1945, di masa Jepang kemudian menjadi Komandan Brigade

156 Haliadi-Sadi, dkk., DPRD Poso 1952-1999: Studi Sejarah Parlemen Lokal, Yogyakarta: Pustaka Timur, 2004

157 Memori Gubernur Kepala daerah Provinsi Sulawesi Tengah 1971, hal. 25.

15836 tahun Sulawesi Tengah Sukseskan Gemabangdesa, hal. vi. 
Kian Santang Siliwangi Purwakarta Jawa Barat tahun 1945-1947. Karir militernya dilaluinya dengan tekun hingga menduduki Kasi V Korem 132 Tadulako tevens 1970-1973. Keaktifannya di Golkar sebagai Sekretaris DPD Golkar Provinsi Sulawesi Tengah menarik dirinya ke dalam dinamika politik Sulawesi Tengah hingga menjadi Bupati Poso. Soegijono 19841989 mantan Komandan Kodim 1307 Poso. Setelah itu dijabat selanjutnya oleh Drs. J.W. Sarapang (Pejabat) 15 Januari-Juni 1989.

Bupati Arief Patanga periode 1989-1999 pada awalnya bekerja sebagai Kepala Seksi Hukum Pada Kantor BKDH Tkt II Poso tahun 1972. ${ }^{159}$ Arief Patangan lahir di Poso pada tanggal 16 Juni 1943. Beliau berasal dari lulusan Universitas Islam Indonesia Fakultas Hukum Perdata, Yogyakarta, pada tahun 1971. Pengalamannya di dunia hukum dilaluinya dengan tekun dan penuh kepastian, dia mulai mengikuti latihan atau praktek kepengacaraan di Pengadilan Yogyakarta sejak tahun 1970-an hingga Pelatihan The urban management studi tour at the instituut for housing and urban development studies in Rotterdam, Belanda, pada tahun 1996. Tokoh yang menyukai aerobik ini penuh dengan pengalaman birokratik dimulai dari Kepala Bagian Urusan DPRD Kabupaten Poso tahun 1972-1974 hingga menjadi Kepala BP-7 Kabupaten Poso tahun 1984-1987. Hingga akhirnya menjadi Bupati selama dua periode, yakni periode 1984-1989 dan periode 1989 hingga tahun 1999. ${ }^{160}$

H. Abdul Muin Pusadan Bupati ke-13 sejak 1999, dia memiliki latarbelakang seorang tenaga pengajar di Universitas Tadulako, Palu. Pada periode tahun 1992-1997, dia menjadi penasehat sekaligus anggota Fraksi Karya Pembangunan di DPRD Provinsi Sulawesi Tengah. Beliau adalah tokoh Islam yang lahir di Bungku pada tanggal 12 Agustus 1945. ${ }^{161}$ Sedangkan, yang berkuasa di Kabupaten Donggala, antara lain: Selepas Abd. Aziz Lamajido sebagai Bupati Donggala, masing-masing diduduki oleh Galib Lasahido (Caretaker 1979), Dr. Yan Moh. Caleb (1979-1984), Saleh Sandagang, S.H. (Caretaker 1984), Drs. H. Ramli Noor (1984-1989) didampingi oleh Sekretaris Daerah Drs. Hi. Said Ladjoma (1985-1990), B. Paliudju (1989-1994), Sahabudin Labadjo (1994-1999), H.N. Bidja (1999-2004), S.Sos., Adam Ardjad Lamarauna 2004-2008, Habir Ponulele (2008-2013).

159 Memori Pelaksanaan Tugas Bupati Kepala Daerah Tingkat II Poso Masa Bakti 1994-1999 (Poso: 1999).

160 Ibid.

161 Memori DPRD Provinsi Sulawesi Tengah 1997. Palu: DPRD Provinsi Sulteng, 1997, hal. 217. 


\section{Kesimpulan}

Ada lima integrasi politik lokal Sulawesi Tengah yang penting dicatat dalam sejarah menuju perwujudan nasionalisme pada masa post-kolonial. Intergrasi Dewan Raja-raja, DPRDS 1951, Pemilu 1955, Konsepsi Masyarakat 1963, dan Pembentukan Provinsi Sulawesi Tengah 1964. Konsepsi Mahasiswa Sulteng merupakan awal dan akhir penentuan Provinsi Sulawesi Tengah. Konsepsi ini memilih Provinsi Sulawesi Tengah dengan posisi wilayah meliputi Kabupaten Donggala dan Kabupaten Poso. Konsepsi ini dikenal dengan nama "Konsepsi Mahasiswa Sulteng" atau biasa disebut konsepsi "Rusdi Toana-Mene Lamakarate."

Secara politik, tokoh-tokoh politik yang menjadi Gubernur Sulawesi Tengah direbut oleh orang Sulawesi Tengah; baru pada masa pemerintahan Gubernur Drs. H. Galib Lasahido yang memulai pemerintahannya pada tahun 1981, kemudian dilanjutkan oleh masing-masing Aziz Lamadjido (1986-1996), H.B. Paliudju (19962001), Aminuddin Ponulele (20012006), H.B. Paliudju (2006-2010), Longki Janggola (2010-sekarang). Namun, sejak lahir Provinsi Sulawesi Tengah pada tahun 1964 direbut oleh orang luar Sulawesi Tengah yang dimulai dari Gubernur pertama Provinsi Sulawesi Tengah oleh Anwar Gelar Datoek Madjo Basah Nan Kuning, Kolonel Mohammad Yasin, A.M. Tambunan, Brigadir Jenderal Moenafri, SH., Kolonel R.H. Eddy
Djandjang Djajaatmadja, dan Mayor Jenderal H. Eddy Sabara. Namun, akhirnya, elit baru dan aristokrat saling berganti menguasai daerah ini seperti yang telah disebutkan.

Pergolakan di Pulau Sulawesi pada tahun 1957-an mendapat tanggapan yang berbeda antara tokohtokoh politik lokal berdasarkan pengalaman individu mereka. Tokoh Asa Bungkundapu seorang pemuda Kristen Pamona menghimpun pemuda Sulawesi Tengah di wilayah Poso untuk mengusir Permesta dari wilayahnya dengan tetap menyatu bersama TNI yang Pro-Kesatuan Republik Indonesia. Variasi perbedaan pandangan dari beberapa tokoh Sulawesi Tengah atas pemekaran Provinsi Sulawesi Tengah dari Provinsi Sulawesi Utara Tengah menjadi bukti bahwa tokoh-tokoh lokal memiliki pandangan sendiri-sendiri terhadap konsep otonomi berdasarkan pengalaman perjuangan masing-masing. Hal itu terwujud dari delapan konsep yang berasal dari delapan tokoh, seumpama: Manoppo, TumakakaTambing, Hamid Syahid Arsyad Pane, Zakaria Imban, Tobing, Ngitung, Nani Wartabone, dan Rusdi Toana-Mene Lamakarate. Konsepsi Rusdi Toana dan Mene Lamakarate yang dilatari oleh pejuang-pejuang pemuda seperti Asa Bungkundapu dari GPST Poso dan K.Z.A. Betalemba dari GPPST Donggala yang memenangkan wacana pembentukan Provinsi Sulawesi Tengah sebagai wujud otonomi daerah waktu itu. 


\section{Daftar Pustaka}

"Ikatan Keluarga Sulawesi Tengah Desak Segera Dibentuknya resimen Induk Untuk Daerah Sulawesi Tengah: Pemuda dan Rakyat Sulawesi Tengah berdiri dibelakang Pemerintah Pusat," Berita Antara, Jum'at, 3 Januari 1958, nomor: 3/A.

36 tahun Sulawesi Tengah Sukseskan Gemabangdesa, hal. Vi.

Alfian, 1971. Hasil Pemilu Tahun 1955 untuk DPR. Jakarta: Leknas.

Arsip nomor: 3/A, Berita Antara, Jum'at, 3 Januari 1958.

Arsip Rahasia Provinsi Sulawesi Nomor Registrasi 331 helai A.

Aser Tandapai, GPST: Gerakan Setengah Hati, belum diterbitkan, 2008.

B. E. Matindas dan Bert Supit, Ventje Sumual Menatap Hanya ke Depan Biografi Seorang Patriot, Filsuf, Gembong Pemberontak, Jakarta: Bina Insani, 1998.

Ef. Toripah, "Sedikit Tentang Watak dan Perjuangan GPST di Sulawesi Tengah, dalam Arsip Provinsi Sulawesi (APS), nomor registrasi: 236.

Elyas Joseph (ed). 1994. Lintasan Perjuangan dan Pengabdian Prajurit Kodam VII Wirabuana.

Makassar: Pembinaan Mental KodamVII Wirabuana.

Feith, H. 1999. Pemilihan Umum 1955 di Indonesia. Jakarta: KPG.

Haliadi dkk. 2004. DPRD Poso 19521999: Studi Sejarah Parlemen
Lokal. Yogyakarta: Pustaka Timur.

Haliadi dkk. 2007. Gerakan Pemuda Sulawesi Tengah (GPST) di Poso 1957-1963: Perjuangan anti Permesta dan Pembentukan Provinsi Sulawesi Tengah. Yogyakarta: Ombak.

Haliadi, GERAKAN PEMUDA SULAWESI TENGAH DI POSO: Antara Otonomi dan Pemikiran Kekuasaan Lokal, Dipresentasikan pada Konferensi Nasional Sejarah IX dan Kongres Masyarakat Sejarawan Indonesia oleh DirektoratJenderal Sejarah dan Burbakala Direktorat Geografi Sejarah Kementerian Kebudayaan dan Pariwisata RI di Jakarta tanggal 5-8 Juli 2011.

Haliadi, Historiografi Lokal daan Nasionalisme di Sulawesi Tengah: Menuju Terbentuknya Nation Character Building di Daerah, Makalah diajukan sebagai bahan FGD yang bertema "Pembentukan Badan Pengkajian dan Pemasyarakatan Empat Pilar Kehidupan Bernegara, Urgensi dan Relevansinya dalam Mewujudkan Nation Character Building," yang diadakan oleh Kerjasama UNTAD dengan MPR RI di SwissBel Hotel, 26 Juli 2011.

Harvey, B.S. 1989a. Pemberontakan Kahar Muzakkar dari Tradisi ke DI/TII, Jakarta: Grafiti Pers, 1989.

Harvey, B.S. 1989b. PERMESTA: Pemberontakan Setengah Hati, Jakarta: Grafitipers. 
Heddy Shri Ahimsa Putra, "Hambatan Budaya Dalam Integrasi Politik: Sulawesi Selatan Pada Abd Ke19," Buletin Antropoplogi, No. 16 tahun VII/1991.

Kabupaten Poso dalam Angka 1996 dan 2001.

Kementerian Penerangan Republik Indonesia, dalam: seri Provinsi Sulawesi (Jakarta), hal.192.

Kodam VII Wirabuana, Lintasan Perjuangan dan Pengabdian Prajurit Kodam VII Wirabuana, Ujung Pandang: Pembinaan Mental Kodan VII Wirabuana, 1994.

M. Amir Arham, dkk. 2005. Membangun Sulawesi Tengah Dengan Pola Terwujudnya Tatanan Masyarakat Madani: Kebijakan dan Obsesi H. Aminuddin Ponulele. Palu: PSKP Sulteng.

Memori DPRD Provinsi Sulawesi Tengah 1997, Palu: DPRD Provinsi Sulteng, 1997.

Memori Gubernur Kepala daerah Provinsi Sulawesi Tengah 1971.

Memori Pelaksanaan Tugas Bupati Kepala Daerah Tingkat II Poso Masa Bakti 1994-1999.

Monografi Kabupaten Poso 1984
Naskah sejarah singkat Terjadinya Pembunuhan 15 Orang Pimpinan dan atau Anggota Pasukan Partisan GPST pada tanggal 10 Desember 1960 di Poso.

R.Z. Leirissa. 1997. PRRI Permesta Strategi Membangun Indonesia Tanpa Komunis Jakarta: Pustaka Utama Grafiti.

Riswandha Imawan. 1992. Peranan Organisasi Massa dan Organisasai Politik. Prisma, No.4, April.

Rusdi Toana dan Abd. Karim Mbouw, Mengungkap Perjuangan Rakyat Sulawesi Tengah di Arena Sejarah Bangsa Indonesia, yang diselenggarakan oleh Panitia Sarasehan Sejarah dan Pembangunan Sulteng Fakultas Sospol UNTAD (Cabang UNHAS) di Palu pada bulan April 1980.

Sutrisno Kutoyo, dkk., 2005. Sejarah Daerah Sulawesi Tengah. Jakarta: Pemda Sulteng dan Dinas Kebudayaan dan Pariwisata.

Syakir Mahid, dkk. (ed), 2009. Sejarah Sosial Sulawesi Tengah. Yogyakarta: Pilar Media.

Wawancara dengan Nico Pelima (Sekretaris GPST Poso) dan Mosialo Tonigi (Komandan Divisi VI GPST) tahun 2007. 